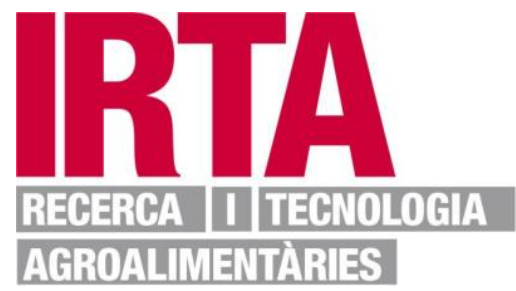

This is a post-peer-review, pre-copyedit version of an article published in Comparative Clinical Pathology. The final authenticated version is available online at: DOI: 10.1007/s00580-017-2551-y 


\title{
Hemato-Immunological and plasma biochemical responses of silvery-black porgy (Sparidentex hasta) fed protein and essential amino acid deficient diets
}

\begin{abstract}
A six-week feeding trial was conducted to evaluate the effects of protein free (PF) and essential amino acid deficient (EAAD) diets on the physiological responses of silvery-black porgy (Sparidentex hasta) juveniles. Three experimental diets were formulated: a control diet in which $60 \%$ of dietary nitrogen was provided by intact protein (fish meal) and $40 \%$ by crystalline AA [(blends of essential amino acids (EAA) and none essential amino acids (NEAA)]; an essential amino acid deficient diet in which $60 \%$ of dietary $\mathrm{N}$ was provided by intact protein, whereas the rest was provided by NEAA; and a protein free (PF) diet, which based on carbohydrate sources. Fish fed the PF and EAAD showed signs of anemia including lower red blood cells counts, hemoglobin and hematocrit levels than control group. Plasma lysozyme activity and complements $\mathrm{C}_{3}$ and $\mathrm{C}_{4}$, as well as total immunoglobulin levels were drastically reduced in fish fed PF and EAAD diets. Plasma and liver alanine aminotransferase, aspartate aminotransferase, lactate dehydrogenase and alkaline phosphatase were significantly increased, but superoxide dismutase was decreased in fish fed PF and EAAD diets. Plasma total protein, albumin, high density lipoprotein, calcium and inorganic phosphorous significantly decreased in fish fed PF and EAAD diets. The information obtained from this study testing to extreme diets (EAAD and PF diets) may serve for better understanding the impact of protein nutritional imbalances in fish.
\end{abstract}

Keywords: Sparidae, digestive enzymes, liver, immune responses, hematology, plasma biochemistry

Running head: Dietary protein and essential amino acids deficiencies in Sparids 


\title{
Introduction
}

Deficiency of protein and the most essential amino acids (EAAs) in the diet results in a reduced weight gain, poor feed efficiency and diminished disease resistance in fish, as protein malnutrition reduces the concentration of most plasma amino acids (AA), and these have an important role in the immune response (Li et al. 2007; 2009; Kiron 2012). Moreover, insufficient intake of proteins or AA ultimately affects the cells' protein content and eventually compromise cellular functionality and viability. Furthermore, there is evidence that AAs play a crucial regulatory role in controlling the turnover of liver proteins and in these sense, several studies have reported liver malfunction in fish fed EAAs imbalance diets (Gao et al. 2014; Li et al. 2016; Zhou et al. 2010). Nevertheless, there is no report concerning the effects of EAA-deficient diet on the liver enzymes in teleosts.

During recent years, several nutritional studies have been focused on establishing the nutritional requirements for improving diet formulation for silvery-black porgy (Sparidentex hasta), since this species has been selected as a candidate for aquaculture diversification in the Persian Gulf and Oman Sea (Mozanzadeh et al. 2017). To our knowledge there is no available information about the effects of dietary protein and EAA deficiencies on the physiological and hematological responses in this species. Thus, the present study aimed to evaluate effects of protein and EAA deficiencies on the hemato-immunological and plasma biochemical parameters and to clarify how protein and EAA deficiencies can affect health indices in this species.

\author{
Materials and methods \\ Experimental diets and fish feeding
}


Three diets were formulated (Tables 1 and 2): a control diet (74.7 g N/kg DM), an essential amino acid deficient diet (EAAD, 76.6 g N/kg DM) and a protein free diet (PF, $7.5 \mathrm{~g} \mathrm{~N} / \mathrm{kg} \mathrm{DM})$. The control diet formulation was according to Marammazi et al. (2017). In the EAAD diet, 60\% of dietary $\mathrm{N}$ was provided by fish meal, whereas the rest was incorporated as a mixture of NEAA (crystalline form). The PF diet was based on wheat middling, corn starch and fish oil. In all diets, ingredients were finely ground, mixed together and then the pre-coated CAA mixture was added, followed by the fish oil and sufficient distilled water to form a soft dough that was extruded to obtain pellets of $2 \mathrm{~mm}$ in size, dried in a convection oven at $25{ }^{\circ} \mathrm{C}$ and stored in re-sealable plastic bags at $-20^{\circ} \mathrm{C}$ until their use.

The study was carried out at the Mariculture Research Station of the South Iranian Aquaculture Research Center (SIARC) (Khuzestan, Sarbandar, Iran). One hundred and thirtyfive juveniles (initial body weight of $4.7 \pm 0.1 \mathrm{~g}$; mean \pm standard deviation) were randomly distributed into 9 cylindrical polyethylene tanks (250 L of volume; 15 fish/tank; 3 replicates per diet). Fish were hand fed each of the experimental diets to visual satiation, three times per day (0800h, 1200h and 1600h) during a period of 42 days. Tanks were supplied with filtered seawater $\left(1 \mathrm{~L} \mathrm{~min}^{-1}\right.$; salinity $48.0 \pm 0.5 \%$; oxygen $7.6 \pm 0.2 \mathrm{mg} \mathrm{L}^{-1} ; \mathrm{pH} 7.8 \pm 0.4$; temperature of $\left.29 \pm 1.5^{\circ} \mathrm{C}\right)$ and subjected to natural photoperiod $\left(30^{\circ} 32 \mathrm{~N}, 49^{\circ} 20^{\prime} \mathrm{E}\right.$; June and July).

\section{Sample collection}

At the end of the trial, fish were fasted for $24 \mathrm{~h}$ before being anaesthetized (2-phenoxyethanol at $0.5 \mathrm{ml} / \mathrm{L}$; Merck, Schuchardt, Germany). Six specimens from each replicate $(\mathrm{n}=18$ per diet, $\mathrm{n}=$ 6 per experimental replicate) were anaesthetized with 2-phenoxyethanol and blood (ca. 250-500 
$\mu 1)$ was collected from the caudal vein with heparinized syringes. An aliquot of blood was used for hematological parameters and two additional aliquots were centrifuged (4,000 $\mathrm{g}, 10 \mathrm{~min}, 4$ ${ }^{\circ} \mathrm{C}$ ) and plasma separated. The vials containing plasma samples were then transferred into liquid nitrogen and stored at $-80{ }^{\circ} \mathrm{C}$ until further analysis.

\section{Plasma and liver biochemical parameters}

Frozen livers were homogenized in 10 volumes (w/v) of ice-cold physiological buffer saline $(\mathrm{NaCl} 0.9 \%, \mathrm{pH} 7.0)$, at $200 \mathrm{rpm}$ for $3 \mathrm{~min}$ (IKA, Ultra-turrax ${ }^{\circledR}$, USA), then homogenates were centrifuged at 3,600 rpm for $15 \mathrm{~min}$ at $4{ }^{\circ} \mathrm{C}$ and the supernatants were collected and stored in aliquots at $-80{ }^{\circ} \mathrm{C}$ for further enzyme quantification (Jaroli and Sharma 2005). Liver and plasma non-specific enzyme including alanine aminotransferase (ALT), aspartate aminotransferase (AST), lactate dehydrogenase (LDH) and alkaline phosphatase (ALP) as well as plasma biochemical parameters such as glucose, total protein, albumin, triglyceride, total cholesterol, high-density lipoprotein (HDL), low density lipoprotein (LDL), calcium and inorganic phosphorous assessed spectrophotometry by means of an auto-analyzer (Technicon RA-1000, Technicon Instruments, New York, NY, USA) using commercial clinical investigation kits (Pars Azmoon Kit, Tehran, Iran). Total superoxide dismutase (t-SOD) activity was measured using a reagent kit (Sigma-Aldrich, Switzerland) according to the manufacturer instructions; absorbance was read using a microplate scanning spectrophotometer (Power Wave HT, BioTek ${ }^{\circledR}$, USA).

\section{Hemato-immunological and plasma biochemical analyses}


Complete blood counts were assessed according to the methods described by Blaxhall \& Daisley (1973) and Lewis et al. (2001). Lysozyme activity was measured using the turbidimetric method according to Ellis (1990). Levels of complement components 3 (C3) and 4 (C4) were measured spectrophotometrically according to the method described by Tang et al. (2008) using the kit from Pars Azmon Co. Ltd. (Tehran, Iran). In brief, plasma samples were automatically mixed with an antibody provided by the test kit and then, an antigen-antibody complex was formed. The change in absorbance was read at $340 \mathrm{~nm}$ over a fixed-time interval (15 min). The change in Plasma total immunoglobulin (Ig) was measured using the method described by Siwicki et al. (1994).

\section{Statistical analysis}

Data were analyzed using SPSS version 15.0 (Chicago, IL, USA). All data are presented as means \pm standard error of the mean. A One-way analysis of variance was performed at a significance level of 0.05 following the confirmation of normality and homogeneity of variance, and the post-hoc Tukey's test was used for multiple comparisons when statistical differences among groups were detected $(P<0.05)$.

\section{Results}

In this study, survival rate decreased in fish fed the EAAD and PF diets in comparison with the control group. Furthermore, growth performance in fish fed the EAAD diet was $122.2 \%$ lower than in fish fed with the control diet $(P<0.05$; Table 3$)$. In addition, fish fed the PF diet lost weight and their final body weight was $190.5 \%$ lower than those fish from the control group. 
In this study, hemato-immunological parameters were drastically affected by dietary protein and EAA deficiencies (Table 4). Fish fed the PF and EAAD diets had lower red blood cell (RBC) and white blood cell (WBC) counts, hematocrit (Hct), hemoglobin (Hb) and mean cell hemoglobin $(\mathrm{MCH})$ values, whereas these groups of fish showed higher mean cell volume (MCV) and mean cell hemoglobin concentration (MCHC) levels than the control group $(P<$ 0.05). The results of the humoral immune parameters showed that plasma $\mathrm{C} 3$ and total Ig in fish fed the control diet was ca. 3 and 4 times higher than in fish fed the EAAD and PF diets, respectively. Furthermore, plasma $\mathrm{C} 4$ decreased in fish fed EAAD and PF diets, as well as plasma lysozyme activity in these groups that was $c a .8$ and 20 times lower than in the control $\operatorname{group}(P<0.05)$.

Plasma ALT in fish fed the control and EAAD diets was $c a .2$ times lower than in fish fed the PF diet, whereas liver ALT in fish fed the control diet was $c a .2$ and 6 times lower than in fish fed the EAAD and PF diets, respectively (Table 5). Plasma AST and ALP in fish fed the control diet was ca. 1.5 and 4 times lower than in fish fed the EAAD and PF diets, respectively; whereas AST and ALP levels in the liver of fish fed the control diet were ca. 2 and 6 times lower than in other groups. Plasma LDH in fish fed the control diet was $c a .1 .5$ and 4 times lower than fish fed the EAAD and PF diets, respectively; however, hepatic LDH levels in fish fed the control diet were $c a .2$ and 5 times lower than in fish fed the EAAD and PF diets, respectively $(P$ $<0.05)$. Total superoxide dismutase activity in plasma and liver was drastically decreased in fish fed both experimental diets, the EAAD and PF diets, in comparison with the control diet. Plasma biochemical parameters were profoundly affected by dietary protein and EAA deficiencies (Table 6). Plasma total protein, albumin, HDL, calcium and inorganic phosphorus were significantly reduced in the EAAD and PF groups in comparison with the control. Meanwhile, 
plasma glucose, triglyceride, total cholesterol and LDL were higher in fish fed the EAAD and PF diets than in the control group $(P<0.05)$.

\section{Discussion}

In the present study, EAAD and PF diets resulted in a significant decrease in fish survival and growth performance. Lower survival in fish fed the EAAD and PF diets might be related to anemia, immunosuppression, and a drastic change in metabolic processes resulting in hyperglycemia, hyperlipidemia, as well as liver malfunction. Generally, deficiency of most EAA in fish leads to failure or loss of appetite, which result in a reduced feed intake and weight gain, as well as lower disease resistance (Wilson 2002). In fact, imbalances in the dietary AA profile tend to lead to an increase in the oxidation of other EAA and NEAA present at normal levels in the feed, which result in reduced protein utilization, protein synthesis and growth performance in fish (Rønnestad et al. 2007).

Amino acids have critical role in hemoglobin synthesis (Wu et al. 2014) and there is also a positive relationship between the values of $\mathrm{RBC}$ and the dietary protein level in different fish species (Abdel-Tawwab et al. 2010; Habte-Tsion et al. 2013). In the current study, fish fed the EAAD and PF diets showed signs of anemia such as lower RBC, $\mathrm{Hb}$ and Hct, which might be as a consequence of disorders in the function of hematopoietic tissues. In addition, plasma complement components have been reported to decrease as a consequence of dietary protein and EAA deficiencies in S. hasta juveniles. As the liver is the main source of complement proteins, hepatic damage, as indicated by high ALT and AST levels, might therefore affect negatively the complement system (Holland and Lambris 2002). Since EAAs have also key role in protein 
synthesis in immunocytes (Calder 2006; Kiron 2012), reduction in plasma lysozyme and total Ig levels in the EAAD and PF groups might result from the disorder in protein synthesis in immunocytes. On the other hand, the PF group showed the lowest humoral immune responses as a consequence of EAA and NEAA deletion of the PF diet, which indicated that the deletion of the NEAA provoked the suppression of the immune function in this experimental group.

In the present study, except for tSOD, all non-specific enzymes levels significantly increased in plasma and liver of fish fed the EAAD and PF diets in comparison to fish fed the control diet. These results might be attributed to the malfunctioning of the liver in the abovementioned groups, as well as due to the damage or disturbance in the integrity of hepatocytes' membrane as it has been also demonstrated in different fish species, when fed EAA imbalance diets (Zhou et al. 2010, Gao et al. 2014, Li et al. 2015). High levels of plasma LDH in fish fed the EAAD and PF diets could be connected with hepatic parenchyma lesions, as it has been also illustrated in other fish species with high levels of serum non-especific enzymes (Popović et al. 2006, Peres et al. 2013). On the other hand, the significant increase in plasma and liver LDH may indicate an increasing trend in the glycolytic process due to the higher metabolic rate in fish fed EAAD and PF diets for withstanding the stress condition derived from protein-free and EAA deficient diets. Drastic reduction in plasma and liver tSOD activity in fish fed the EAAD and PF diets might be due to non-specific cellular immune response suppression, as it has been also reported in other fish species fed EAA deficient diets (Kuang et al. 2012, Zhao et al. 2013, Wen et al. 2014). High levels of plasma and liver non-specific enzymes in fish fed PF and EAAD diets indicated these EAAs had significant role in structural integrity of the hepatic parenchyma as well as its function. 
As all the plasma proteins with the exception of immunoglobulins are synthesized in the liver (Rosalki and Mcintyre 1999); thus, the decrease in plasma protein in fish fed the EAAD and PF diets suggested a malfunctioning of this organ in these groups, which was confirmed by their higher levels of plasmatic ALT and AST (Welker and Congleton 2003). In this study, fish fed EAAD and PF diets had lower plasma albumin levels than the control group, which indicated a severe hepatic damage in these groups, since albumin is solely synthesized by the liver (Rosalki and Mcintyre 1999). The results of this study showed that fish fed the EAAD and PF diets had the higher plasma glucose than the control group, which might be considered as a consequence for the chronic stress condition of these fish, as it has been reported in many fish species (Barcellos et al. 1999, Barcellos et al. 2009). The highest plasma glucose in the PF group, which may be also attributed to the high levels of carbohydrates in the PF diet that were included to match the energetic needs of the species under the experimental dietary protein restriction evaluated in this study. These results are in agreement with those recently reported by Mozanzadeh et al. (2016), the former authors reported that high plasma glucose levels in S. hasta juveniles fed high carbohydrate to lipid ratio diets. In this context, limited ability of metabolizing glucose in most fish species results in a hyperglycaemic condition in fish fed with high carbohydrate levels (Booth et al. 2013) diet. The results of the current study showed that fish fed the EAAD and PF diets had the highest plasma cholesterol, triglyceride and LDL levels, suggesting a hepatic and intestinal dysfunction in lipoprotein synthesis. In addition, plasma HDL was significantly decreased in fish fed the EAAD and PF diets, which may be attributed to a disorder in synthesis of apolipoproteins, as well as plasma phospholipid transfer protein in these groups. As the main part of plasmatic $\mathrm{Ca}^{2+}$ bounds to plasmatic proteins, it seemed plausible that the significant decrease in plasma $\mathrm{Ca}^{2+}$ content in fish fed the EAAD and PF diets could be 
related to the decrease in plasma total protein content. As the digestive tract is the major absorptive epithelium for phosphorus in fish (Hua and Bureau 2006), damaging the intestine epithelium may led to the decrease in plasma phosphorus content in fish fed the PF and EAAD diets.

\section{Conclusion}

The results of this study showed that dietary protein and EAA deficiencies had drastic disorders on humoral immune responses and these groups showed signs of anemia. Fish fed the PF and EAAD diets showed high levels of liver and plasma non-specific enzymes activities in comparison with the control group, indicating the liver damages. Moreover, plasma health indices drastically changed in fish fed the PF and EAAD diets, suggesting a critical function of the protein and EAA on different metabolic pathways of fish. The information obtained from this study testing to extreme diets (EAAD and PF diets) may serve for better understanding the impact of protein nutritional imbalances in fish, as well as generate reference values for a large series of physiological parameters under unsuitable nutritional conditions.

\section{Compliance with ethical standards}

Funding: This study was funded by Iran National Science Foundation (grant number 92011610).

Conflict of interest: There is no conflict of interest between authors in the publication of this paper.

Ethical approval: All applicable international, national, and/or institutional guidelines for the care and use of animals were followed. 


\section{References}

Abdel-Tawwab M, Ahmad MH, Khattab YA, Shalaby AM (2010) Effect of dietary protein level, initial body weight, and their interaction on the growth, feed utilization, and physiological alterations of Nile tilapia, Oreochromis niloticus (L.). Aquaculture 298:267-274

Barcellos L, Nicolaiewsky S, De Souza S, Lulhier F (1999) Plasmatic levels of cortisol in the response to acute stress in Nile tilapia, Oreochromis niloticus (L.), previously exposed to chronic stress. Aquacult. Res. 30:437-444

Barcellos LJG, Kreutz LC, Quevedo RM, da Rosa JGS, Koakoski G, Centenaro L, Pottker E (2009) Influence of color background and shelter availability on jundiá (Rhamdia quelen) stress response. Aquaculture 288, 51-56

Blaxhall P, Daisley K (1973) Routine haematological methods for use with fish blood. J. Fish Biol. 5:771-781

Booth MA, Moses MD, Allan GL (2013) Utilisation of carbohydrate by yellowtail kingfish Seriola lalandi. Aquaculture 376-379:151-161

Calder PC (2006) Branched-chain amino acids and immunity. J. Nutr. 136:288-293

Ellis AE (1990) Lysozyme assays. In: Techniques in Fish Immunology (Stolen JS, Fletcher TC, Anderson DP, Robertson BS, van Muisvinkel WB (Eds), SOS Publications, Fair Haven, NJ, USA, pp.101-103

Gao YJ, Yang HJ, Liu YJ, Chen SJ, Guo DQ, Yu,YY, Tian LX (2014) Effects of graded levels of threonine on growth performance, biochemical parameters and intestine morphology of juvenile grass carp Ctenopharyngodon idella. Aquaculture 424:113-119

Habte-Tsion H-M, Liu B, Ge X, Xie J, Xu P, Ren M, Zhou Q, Pan L, Chen R (2013) Effects of dietary protein level on growth performance, muscle composition, blood composition, and 
digestive enzyme activity of Wuchang bream (Megalobrama amblycephala) fry. Israel. J. Aquacul. 65:925-933

Holland MCH, Lambris JD (2002) The complement system in teleosts. Fish. Shellfish Immunol. $12: 399-420$

Hua K, Bureau, DP (2006) Modelling digestible phosphorus content of salmonid fish feeds. Aquaculture 254:455-465

Kiron V (2012) Fish immune system and its nutritional modulation for preventive health care. Anim. Feed Sci. Tech. 173:111-133

Lewis S, Bain B, Bates ID (2001) Lewis practical haematology. Churchill Livingstone, New York, USA.

Kuang S-Y, Xiao W-W, Feng L, Liu Y, Jiang, J, Jiang W-D, Hu K, Li S-H, Tang L, Zhou X-Q (2012) Effects of graded levels of dietary methionine hydroxy analogue on immune response and antioxidant status of immune organs in juvenile Jian carp (Cyprinus carpio var. Jian). Fish. Shellfish Immunol. 32, 629-636.

Jaroli D, Sharma B (2005) Effect of Organophosphate Insecticide on the Organic Constituents in Liver of Channa punctatuus. Asian J. Experiment. Sci. 19:121-129

Li P, Yin Y-L, Li D, Kim SW, Wu G (2007) Amino acids and immune function. Brit. J. Nutr. 98: $237-252$

Li P, Mai K, Trushenski J, Wu G (2009) New developments in fish amino acid nutrition: towards functional and environmentally oriented aquafeeds. Amino acids 37:43-53

Li W, Feng L, Liu Y, Jiang WD, Kuang SY, Jiang J, Li SH, Tang L, Zhou XQ (2015) Effects of dietary phenylalanine on growth, digestive and brush border enzyme activities and antioxidant 
capacity in the hepatopancreas and intestine of young grass carp (Ctenopharyngodon idella). Aquacult. Nutr. 21:913-925

Marammazi JG, Yaghoubi M, Safari O, Peres H, Mozanzadeh MT (2017) Establishing the optimum dietary essential amino acids pattern for silvery-black porgy (Sparidentex hasta) juveniles by deletion method. Aquac. Nutr. 00:1-9

Mozanzadeh MT, Yavari V, Marammazi J, Agh N, Gisbert E (2016) Optimal dietary carbohydrate-to-lipid ratios for silvery-black porgy (Sparidentex hasta) juveniles. Aquacult. Nutr. 00, 1-14

Mozanzadeh MT, Marammazi JG, Yaghoubi M, Agh N, Pagheh E, Gisbert E (2017) Macronutrient Requirements of Silvery-Black Porgy (Sparidentex hasta): A Comparison with Other Farmed Sparid Species. Fishes 2(2):5

Peres H, Santos S, Oliva Teles A (2013) Selected plasma biochemistry parameters in gilthead seabream (Sparus aurata) juveniles. J. App. Ichthyol. 29:630-636

Popović NT, Strunjak-Perović I, Čož-Rakovac R, Hacmanjek M (2006) Plasma metabolites and enzymes of bluefin tuna, Thunnus thynnus and liver histology. Periodicum biologorum 108:127131

Rønnestad I, Kamisaka Y, Conceição L, Morais S, Tonheim S (2007) Digestive physiology of marine fish larvae: hormonal control and processing capacity for proteins, peptides and amino acids. Aquaculture 268:82-97

Rosalki S, Mcintyre NI (1999) Biochemical investigations in the management of liver disease. Oxford Text. Clinic. Hepatol. 2:503-521 
Siwicki AK, Anderson DP, Rumsey GL (1994) Dietary intake of immunostimulants by rainbow trout affects non-specific immunity and protection against furunculosis. Vet. Immunol. Immunopatho. 41:125-139

Tang HG, Wu TX, Zhao ZY Pan XD (2008) Effects of fish protein hydrolysate on growth performance and humoral immune response in large yellow croaker (Pseudosciaena crocea $\mathrm{R}$.). J. Zhejiang Univ. Sci. B. 9:684-690

Welker TL, Congleton JL (2003) Relationship between dietary lipid source, oxidative stress, and the physiological response to stress in sub-yearling chinook salmon (Oncorhynchus tshawytscha). Fish Physiol Biochem29: 225-235

Wen H, Feng L, Jiang W, Liu Y, Jiang J, Li S, Tang L, Zhang Y, Kuang S, Zhou X (2014) Dietary tryptophan modulates intestinal immune response, barrier function, antioxidant status and gene expression of TOR and NRF2 in young grass carp (Ctenopharyngodon idella). Fish. Shellfish Immunol. 40:275-287

Wilson RP (2002) Amino Acids and Proteins. In: Fish Nutrition (Third Edition) (Hardy JEHW ed.), pp. 143-179. Academic Press, San Diego, USA

Wu G, Bazer F, Dai Z, Li D, Wang J, Wu Z (2014) Amino acid nutrition in animals: protein synthesis and beyond. Ann. Rev. Anim. Biosci. 2:387-417

Zhao J, Liu Y, Jiang J, Wu P, Jiang W, Li S, Tang L, Kuang S, Feng L, Zhou X (2013) Effects of dietary isoleucine on the immune response, antioxidant status and gene expression in the head kidney of juvenile Jian carp (Cyprinus carpio var. Jian). Fish. Shellfish Immunol. 35:572-580 Zhou F, Xiong W, Xiao JX, Shao QJ, Bergo ON, Hua Y, Chai X (2010) Optimum arginine requirement of juvenile black sea bream, Sparus macrocephalus. Aquacult. Res. 41:418-430 


\section{Table 1}

Ingredient and proximate composition of the control, essential amino acids deficient (EAAD) and protein free (PF) diets.

\begin{tabular}{|c|c|c|c|}
\hline \multirow[b]{2}{*}{ Dietary ingredients ( $\mathrm{g} \mathrm{kg}^{-1}$ dry diet) } & \multicolumn{3}{|c|}{ Diets } \\
\hline & Control & EAAD & $\mathrm{PF}$ \\
\hline Fish meal ${ }^{\mathrm{a}}$ & 360 & 360 & - \\
\hline Gelatin $^{\mathrm{b}}$ & 40 & 40 & - \\
\hline Wheat middling ${ }^{\mathrm{c}}$ & 70 & 70 & 275 \\
\hline Corn starch ${ }^{\mathrm{d}}$ & 205 & 205 & 540 \\
\hline Fish oil $^{a}$ & 110 & 110 & 155 \\
\hline $\operatorname{Agar}^{\mathrm{f}}$ & 10 & 10 & 10 \\
\hline Vitamin Premix ${ }^{g}$ & 10 & 10 & 10 \\
\hline Mineral Premix ${ }^{h}$ & 10 & 10 & 10 \\
\hline L-arginine & 8.5 & - & - \\
\hline L-lysine- $\mathrm{HCl}$ & 11.5 & - & - \\
\hline L-threonine & 8 & - & - \\
\hline L-histidine & 5 & - & - \\
\hline L-isoleucine & 8.5 & - & - \\
\hline L-leucine & 14 & - & _- \\
\hline L-methionine & 6 & - & - \\
\hline L-phenylalanine & 7.5 & - & - \\
\hline L-tryptophan & 2 & - & - \\
\hline L-valine & 9.5 & - & - \\
\hline DAA mixture ${ }^{\mathrm{i}}$ & 104.5 & 185 & - \\
\hline \multicolumn{4}{|l|}{ Proximate composition (\%) } \\
\hline Dry matter & $92.9 \pm 0.4$ & $93.2 \pm 0.1$ & $91.5 \pm 0.3$ \\
\hline Crude protein & $46.7 \pm 0.6$ & $47.9 \pm 0.1$ & $4.7 \pm 2.5$ \\
\hline Crude lipid & $20.1 \pm 0.0$ & $20.0 \pm 0.0$ & $19.9 \pm 0.6$ \\
\hline Crude fiber & $1.1 \pm 0.0$ & $0.5 \pm 0.0$ & $1.9 \pm 0.6$ \\
\hline $\mathrm{NFE}^{\mathrm{j}}$ & $19.1 \pm 0.5$ & $18.3 \pm 0.2$ & $64.3 \pm 1.7$ \\
\hline Ash & $6.8 \pm 0.1$ & $6.1 \pm 0.1$ & $1.6 \pm 0.0$ \\
\hline Gross energy $\left(\mathrm{kJ} \mathrm{g}^{-1}\right)^{\mathrm{k}}$ & $20.9 \pm 0.1$ & $20.1 \pm 0.0$ & $19.5 \pm 0.0$ \\
\hline
\end{tabular}

${ }^{\mathrm{a}}$ Fish meal (Clupeonella sp.); Parskilka Mazandaran, Iran (63.5\% crude protein, $17.7 \%$ crude lipid);

${ }^{\mathrm{b}}$ Gelatine; Beyza feed mill, Shiraz, Iran. (85\% crude protein, crude lipid, 4.2);

${ }^{\mathrm{c}}$ Wheat meal; Beyza feed mill, Shiraz, Iran.12\% crude protein, $3 \%$ crude lipid)].

${ }^{\mathrm{d}}$ Corn starch, Beyza feed mill, Shiraz, Iran.

'Parskilka Mazandaran, Iran (Clupeonella sp.).

${ }^{\mathrm{f}}$ Merck, Germany

gVitamin premix ( $\left.\mathrm{mg} \mathrm{kg}^{-1}\right)$ of premix: vitamin A, $5000000 \mathrm{IU}$; vitamin D3, $500000 \mathrm{IU}$; vitamin E, $3000 \mathrm{mg}$; vitamin K3, 1500; vitamin B1, 6000; vitamin B2, 24000; vitamin B5, 52000; vitamin B6, 18000; vitamin B12, 60000; folic acid, 3000; nicotinamide 180000; antioxidant, 500, Damloran pharmaceutical company, Broujerd, Iran.

${ }^{\text {h} M i n e r a l ~ p r e m i x ~}\left(\mathrm{mg} \mathrm{kg}^{-1}\right.$ ) of premix: copper, 3000; zinc, 15000; manganese, 20000; Iron, 10000 ; potassium iodate, 300. Microvit $\AA$, Razak laboratories, Tehran, Iran.

Crystalline amino acids: Merck, Germany, except isoleucine (Sigma-Aldrich, USA)

'Dispensable amino acids mixture (\% mixture): L-alanine: 13; L-aspartic acid: 20; sodium glutamate: 32; L-glycine:

15; L-serine: 10; and L-proline: 10, Merck, Germany.

${ }^{\mathrm{j}}$ Nitrogen-free extract $=100-($ protein + lipid + ash + fiber $)$.

${ }^{\mathrm{k}}$ Gross energy content was estimated as: total carbohydrate $\times 17.2 \mathrm{~J} \mathrm{~kg}^{-1}$; fat $\times 39.5 \mathrm{Jkg}^{-1}$; and protein $\times 23.5 \mathrm{~J} \mathrm{~kg}^{-1}$. 
Table2.

Amino acids profile of the control, essential amino acids deficient (EAAD) and protein free $(P F)$ diets $(n=$ 1), g $100 \mathrm{~g}^{-1}$ Diet

\begin{tabular}{lccc}
\hline Amino acid composition & Control & EAAD & PF \\
\hline Arginine & 2.6 & 1.7 & 0.2 \\
Lysine & 2.2 & 1.3 & 0.2 \\
Threonine & 1.9 & 1.9 & 0.2 \\
Histidine & 1.2 & 0.7 & 0.1 \\
Isoleucine & 2.1 & 1.2 & 0.3 \\
Leucine & 2.4 & 1.5 & 0.3 \\
Methionine & 1.4 & 0.8 & 0.1 \\
Cysteine* & 0.3 & 0.3 & 0.1 \\
Phenylalanine & 1.8 & 1.1 & 0.3 \\
Tyrosine & 0.9 & 0.9 & 0.2 \\
Tryptophan & \\
Valine & 0.5 & 0.3 & 0.1 \\
Alanine & 2.1 & 1.3 & 0.3 \\
Aspartate & 3.6 & 4.4 & 0.2 \\
Glutamate & 5.5 & 6.7 & 0.3 \\
Glycine & 7.8 & 9.8 & 0.3 \\
Proline & 5.0 & 6.0 & 0.3 \\
Serine & 2.3 & 3.0 & 0.2 \\
\hline
\end{tabular}




\section{Table 3.}

Growth performance of $S$. hasta juvenile fed control, essential amino acids deficient (EAAD) and protein free (PF) diets (means $\pm \mathrm{SE}, \mathrm{n}=3$ ). A different superscript in the same row denotes statistically significant differences $(P<$ $0.05)$.

\begin{tabular}{|c|c|c|c|}
\hline & \multicolumn{3}{|c|}{ Diets } \\
\hline & Control & EAAD & $\mathrm{PF}$ \\
\hline $\mathrm{BW}_{\mathrm{i}}(\mathrm{g})$ & $4.6 \pm 0.1$ & $4.6 \pm 0.0$ & $4.6 \pm 0.0$ \\
\hline $\mathrm{BW}_{\mathrm{f}}(\mathrm{g})$ & $12.8 \pm 0.5^{\mathrm{a}}$ & $7.2 \pm 0.3^{\mathrm{b}}$ & $4.0 \pm 0.1^{\mathrm{c}}$ \\
\hline $\mathrm{S}(\%)$ & $100.0 \pm 0.0^{\mathrm{a}}$ & $91.1 \pm 3.1^{\mathrm{b}}$ & $74.4 \pm 2.2^{c}$ \\
\hline $\mathrm{WG}(\%)^{1}$ & $177.0 \pm 5.9^{\mathrm{a}}$ & $54.8 \pm 0.6^{\mathrm{b}}$ & $-13.5 \pm 2.2^{c}$ \\
\hline
\end{tabular}

${ }^{1}$ weight gain $=\left[\left(\mathrm{BW}_{\mathrm{f}}-\mathrm{BW}_{\mathrm{i}}\right) / \mathrm{BW}_{\mathrm{i}}\right] \times 100$ 


\section{Table 4}

Hemato-immunological parameters of $S$. hasta juvenile fed control, essential amino acids deficient (EAAD) and protein free $(\mathrm{PF})$ diets (means $\pm \mathrm{SE}, \mathrm{n}=3$ ).

\begin{tabular}{|c|c|c|c|}
\hline & \multicolumn{3}{|c|}{ Dietary treatments } \\
\hline & Control & DAAD & PF \\
\hline \multicolumn{4}{|c|}{ Hematological parameters } \\
\hline $\mathrm{RBC}\left(\times 10^{6} \mu \mathrm{L}\right)$ & $1.8 \pm 0.0^{\mathrm{a}}$ & $1.5 \pm 0.1^{\mathrm{b}}$ & $0.5 \pm 0.0^{c}$ \\
\hline $\mathrm{WBC}\left(\times 10^{3} \mu \mathrm{L}\right)$ & $13.9 \pm 0.8^{\mathrm{a}}$ & $13.5 \pm 0.4^{\mathrm{a}}$ & $12.2 \pm 0.1^{\mathrm{b}}$ \\
\hline Hct $(\%)$ & $32.0 \pm 1.0^{\mathrm{ab}}$ & $35.3 \pm 3.5^{\mathrm{a}}$ & $25.0 \pm 1.2^{\mathrm{b}}$ \\
\hline $\mathrm{Hb}\left(\mathrm{g} \mathrm{dL}^{-1}\right)$ & $4.8 \pm 0.2^{\mathrm{a}}$ & $3.5 \pm 0.1^{b}$ & $2.4 \pm 0.2^{\mathrm{c}}$ \\
\hline $\operatorname{MCV}\left(\mathrm{mm}^{3}\right)$ & $178.6 \pm 7.2^{\mathrm{c}}$ & $229.4 \pm 20.0^{\mathrm{b}}$ & $471.5 \pm 3.7^{\mathrm{a}}$ \\
\hline $\mathrm{MCH}\left(\mathrm{pg}\right.$ cell $\left.^{-1}\right)$ & $26.7 \pm 0.7^{\mathrm{b}}$ & $22.6 \pm 0.6^{\mathrm{c}}$ & $45.6 \pm 0.6^{\mathrm{a}}$ \\
\hline $\mathrm{MCHC}\left(\mathrm{g} \mathrm{dL}^{-1}\right)$ & $15.0 \pm 0.1^{\mathrm{a}}$ & $10.0 \pm 0.1^{\mathrm{b}}$ & $10.0 \pm 0.1^{b}$ \\
\hline \multicolumn{4}{|c|}{ Immunological parameters } \\
\hline Total $\mathrm{Ig}\left(\mu \mathrm{g} \mathrm{mL} L^{-1}\right)$ & $4.4 \pm 0.6^{\mathrm{a}}$ & $1.3 \pm 0.0^{\mathrm{b}}$ & $1.1 \pm 0.0^{c}$ \\
\hline $\mathrm{C} 3\left(\mu \mathrm{g} \mathrm{mL}^{-1}\right)$ & $488.0 \pm 70.0^{\mathrm{a}}$ & $146.0 \pm 12.0^{\mathrm{b}}$ & $124.0 \pm 15.0^{c}$ \\
\hline $\mathrm{C} 4\left(\mu \mathrm{g} \mathrm{mL} L^{-1}\right)$ & $340.0 \pm 42.0^{\mathrm{a}}$ & $32.0 \pm 2.0^{\mathrm{b}}$ & $12.0 \pm 4.0^{\mathrm{c}}$ \\
\hline Lysozyme $\left(\mu \mathrm{g} \mathrm{mL}^{-1}\right)$ & $4.1 \pm 0.2^{\mathrm{a}}$ & $0.5 \pm 0.0^{\mathrm{b}}$ & $0.2 \pm 0.1^{\mathrm{c}}$ \\
\hline
\end{tabular}




\section{Table 5}

Non-specific enzyme activities in plasma and liver of $S$. hasta juvenile fed control, essential amino acids deficient (EAAD) and protein free (PF) diets (means $\pm \mathrm{SE}, \mathrm{n}=3$ ).

\begin{tabular}{|c|c|c|c|}
\hline & \multicolumn{3}{|c|}{ Dietary treatments } \\
\hline & Control & EAAD & $\mathrm{PF}$ \\
\hline \multicolumn{4}{|l|}{ Plasma } \\
\hline $\operatorname{ALT}\left(\mathrm{U} \mathrm{L}^{-1}\right)$ & $210.8 \pm 2.8^{\mathrm{b}}$ & $205.4 \pm 14.9^{\mathrm{b}}$ & $433.7 \pm 46.1^{\mathrm{a}}$ \\
\hline $\operatorname{AST}\left(\mathrm{UL}^{-1}\right)$ & $244.9 \pm 2.9^{c}$ & $319.5 \pm 19.2^{\mathrm{b}}$ & $777.7 \pm 66.0^{\mathrm{a}}$ \\
\hline $\operatorname{LDH}\left(\mathrm{U} \mathrm{L}^{-1}\right)$ & $34.2 \pm 0.4^{\mathrm{c}}$ & $49.8 \pm 2.8^{\mathrm{b}}$ & $126.3 \pm 10.0^{\mathrm{a}}$ \\
\hline $\operatorname{ALP}\left(\mathrm{U} \mathrm{L}^{-1}\right)$ & $226.9 \pm 2.6^{c}$ & $330.8 \pm 18.6^{\mathrm{b}}$ & $838.0 \pm 66.5^{\mathrm{a}}$ \\
\hline $\operatorname{SOD}\left(\mathrm{U} \mathrm{L}^{-1}\right)$ & $87.8 \pm 1.0^{\mathrm{a}}$ & $1.4 \pm 0.1^{\mathrm{c}}$ & $0.2 \pm 0.0^{c}$ \\
\hline \multicolumn{4}{|l|}{ Liver } \\
\hline ALT (U mg ${ }^{-1}$ protein) & $2.9 \pm 0.3^{c}$ & $5.3 \pm 1.8^{\mathrm{b}}$ & $17.0 \pm 1.1^{\mathrm{a}}$ \\
\hline AST ( $\mathrm{U} \mathrm{mg}^{-1}$ protein $)$ & $2.9 \pm 0.1^{c}$ & $5.1 \pm 1.6^{\mathrm{b}}$ & $15.6 \pm 4.1^{\mathrm{a}}$ \\
\hline $\mathrm{LDH}\left(\mathrm{U} \mathrm{mg}^{-1}\right.$ protein $)$ & $1.5 \pm 0.1^{\mathrm{c}}$ & $2.6 \pm 0.1^{\mathrm{b}}$ & $8.1 \pm 0.1^{\mathrm{a}}$ \\
\hline $\operatorname{ALP}\left(\mathrm{U} \mathrm{mg}^{-1}\right.$ protein $)$ & $2.8 \pm 0.2^{\mathrm{c}}$ & $5.4 \pm 0.1^{\mathrm{b}}$ & $17.6 \pm 1.1^{\mathrm{a}}$ \\
\hline SOD (U mg ${ }^{-1}$ protein) & $2.7 \pm 0.3^{\mathrm{a}}$ & $0.1 \pm 0.0^{\mathrm{b}}$ & $0.01 \pm 0.0^{c}$ \\
\hline
\end{tabular}




\section{Table 6}

Plasma biochemical parameters of $S$. hasta juvenile fed control, essential amino acids deficient $(\mathrm{EAAD})$ and protein free $(\mathrm{PF})$ diets (means $\pm \mathrm{SE}, \mathrm{n}=3$ ).

\begin{tabular}{lccc}
\hline & \multicolumn{3}{c}{ Dietary treatments } \\
\hline & Control & EAAD & PF \\
\cline { 2 - 4 } Total Protein $\left(\mathrm{g} \mathrm{L}^{-1}\right)$ & $29.0 \pm 3.0^{\mathrm{a}}$ & $4.3 \pm 0.2^{\mathrm{b}}$ & $2.8 \pm 0.1^{\mathrm{c}}$ \\
Albumin $\left(\mathrm{g} \mathrm{L}^{-1}\right)$ & $19.6 \pm 0.1^{\mathrm{a}}$ & $0.3 \pm 0.0^{\mathrm{b}}$ & $0.2 \pm 0.0^{\mathrm{b}}$ \\
Glucose $\left(\mathrm{mg} \mathrm{dL}^{-1}\right)$ & $134.0 \pm 7.0^{\mathrm{c}}$ & $145.2 \pm 8.0^{\mathrm{b}}$ & $231.6 \pm 14.0^{\mathrm{a}}$ \\
Triglyceride $\left(\mathrm{mg} \mathrm{dL}^{-1}\right)$ & $70.5 \pm 0.8^{\mathrm{c}}$ & $77.4 \pm 0.6^{\mathrm{b}}$ & $163.9 \pm 5.4^{\mathrm{a}}$ \\
Cholesterol $\left(\mathrm{mg} \mathrm{dL}^{-1}\right)$ & $40.4 \pm 1.1^{\mathrm{c}}$ & $166.5 \pm 18.9^{\mathrm{b}}$ & $269.5 \pm 15.5^{\mathrm{a}}$ \\
$\mathrm{HDL}\left(\mathrm{mg} \mathrm{dL}^{-1}\right)$ & $34.0 \pm 0.0^{\mathrm{a}}$ & $0.2 \pm 0.0^{\mathrm{b}}$ & $0.1 \pm 0.0^{\mathrm{c}}$ \\
$\mathrm{LDL}\left(\mathrm{mg} \mathrm{dL}^{-1}\right)$ & $3.6 \pm 0.1^{\mathrm{c}}$ & $152.2 \pm 21.0^{\mathrm{b}}$ & $236.6 \pm 14.4^{\mathrm{a}}$ \\
$\mathrm{Ca}\left(\mathrm{mg} \mathrm{dL}^{-1}\right)$ & $8.8 \pm 0.2^{\mathrm{a}}$ & $0.8 \pm 0.0^{\mathrm{b}}$ & $0.4 \pm 0.0^{\mathrm{c}}$ \\
$\mathrm{P}\left(\mathrm{mg} \mathrm{dL}^{-1}\right)$ & $1.5 \pm 0.0^{\mathrm{a}}$ & $0.9 \pm 0.0^{\mathrm{b}}$ & $0.9 \pm 0.0^{\mathrm{b}}$ \\
\hline
\end{tabular}

